\title{
Association of oral health-related behaviour and dental caries among 6 -7 year old school childrens of wilsonia pakwara Moradabad:Across sectional study
}

\begin{abstract}
Aim: To find out the association of the oral health related behavior and dental caries

Methods: A cross-sectional study was conducted on the 6-7 year old students of wilsonia school, dft was clinically assessed at the first visit and validated questionnaire was distributed among the parents of the students. Questionnaire consists of the three main questions, one regarding the tooth brushing Frequency that was assessed by the following question: "How many times a day does your child brush his/her teeth?" with the answers of "twice or more/day," "once/day," "less than once/day," and "do not know." These answers were recorded as "twice or more/day; coded 1" and "less than twice/day (including 'do not know'); coded 2". Another question regarding the drinking sugar-sweetened beverages frequency was assessed by the following question: "How often does your child drink sugar-sweetened beverages?" with the answers of "several times/month or never; coded 1," "once/week; coded 2," "2- 3 times/week; coded 3," "4-6 times/week; coded 4," "once/day; coded 5" and "twice or more/day; coded 6." Third question was regarding "Snack-eating habits" that was assessed by the following question: "When does your child eat snacks?" with the answer of "does not eat snacks; coded 1," "eats snacks at a set time; coded 2" and "eats snacks freely whenever he/she wants; coded 3."

Results: Poor oral behavior was associated with higher dft after adjusting for all covariates Toothbrushing frequency, frequency of drinking sugar-sweetened beverages and snack-eating habits $(\mathrm{OR}=1.49, \mathrm{Cl}-1.17-1.89)(\mathrm{OR}=2.01,95 \% \mathrm{Cl}=1.27,3.18)$ and $(\mathrm{OR}=1.83,95 \% \mathrm{Cl}=1.14,2.92)$ associated with dft,

Conclusions: by improving children's oral health behavior might decrease their dental caries

by Strengthening their self control.
\end{abstract}

Keywords : Child, child dentistry, dental caries, oral health behavior

\section{Introduction:}

Dental caries is a multifactorial disease so it is not possible that any specific factor can be called as etiology of the dental caries.As the increased prevalence of dental carries among the children is an alarming situation for the developing countries. So this part of health problem cannot be ignored at all .Dental caries status in the primary dentition influences on the dental status of the permanent dentition as well. So maintenance of oral behavior at an early stage not only has beneficial effect at childhood but also at the adulthood as well.

Oral health and general health are interlinked with each other. By maintaining the oral health many diseases are prevented.

\begin{tabular}{|l|c|}
\hline \multicolumn{2}{|c|}{ Access this article online } \\
\hline \multirow{2}{*}{$\begin{array}{l}\text { Website: } \\
\text { www.ujds.in }\end{array}$} & Quick Response Code \\
\hline $\begin{array}{l}\text { DOI: } \\
\text { https://doi.org/10.21276/ujds.2020.6.3.7 }\end{array}$ \\
\hline
\end{tabular}

Despite of so many studies done on the causative factors of the dental caries still the burden of the caries is increasing. Literacy is the factor of dental caries that has been given not so importance before "The American Dental Association (ADA) defines OHL as the degree to which individuals have

\author{
${ }^{1}$ ABDULLAH, S., ${ }^{2}$ KHAZIR, M. \\ ${ }^{1}$ Resident Public Health Dentistry, \\ TMU Moradabad \\ 2Deptt of Prosthodontics, \\ Aligarh Muslim University, Aligarh
}
Address for Corresponding : Mahbooba Khazir Resident Public Health Dentistry TMU, Moradabad

Received : 5 Nov. 2020, Published : 31 Dec. 2020

How to cite this article: Abdullah, S., \& Khazir, M. (2021). The association of oral health-related behaviour and dental caries among $6-7$ year old school children of Wilsonia Pakwara Moradabad : Across sectional study. UNIVERSITY JOURNAL OF DENTAL SCIENCES, 6(3). 
the capacity to obtain, process, and understand basic health information and services needed to make appropriate oral health decisions"

Many researchers before have found association between oral behavior and dental caries status (DMFT) like Haridas et al" in 2011 in India and "Haerian Ardakani et al" in 2012 in Iran. Another researcher namely "Vann et al" in 2015 also conducted a study to found the effect of OHLQOL on the health of the young children. In our country there is almost negligible attention paid to the preventive measures and more attention is given to the curative services by dentists .

Hence this study was conducted to find out the association of oral health-related behaviour and dental caries in school going children of wilsonia school pakwara Moradabad to highlight the importance of prevention.

\section{Materials and method}

\section{STUDY AREA}

The MORADABAD district is situated in north-west of the state capital lucknow U.P .It is situated on the banks of Ramganga, at a distance of $167 \mathrm{~km}$ from the national capital, New Delhi. In MORADABAD temperature in summers is $43^{\circ} \mathrm{C}-300 \mathrm{C}$ and in winter's temperature is $25^{\circ} \mathrm{C}-50 \mathrm{C}$. According to Census 2011, the area of Moradabad district is 349.00 sq. km.. Its total population is 889,810 out of which males are 15,01,927 and females are 12,49,094. Of the total population, 16,39, 935 constitutes the rural population and $11,11,086$ belong to the urban population

Source Of Data: Data were collected through a survey which included clinical examination and structured questionnaire

Study Population: A cross-sectional study was conducted on the 6-7 year old students of wilsonia school

Based on the results of the pilot study sample size was calculated by the formula $\mathrm{n}=\mathrm{Z} 2\{\mathrm{p}(1-\mathrm{p})\} / \mathrm{e} 2$ as 450.Students who were present on the day of examination and willing for the study and were 6-7 year age group were included in the study.Ethical clearance for the study was obtained by the Ethical Committee of Teerthanker Mahaveer Dental College \& Research Centre and Permission to conduct the survey was obtained from the respective education authorities. informed consent was taken from each subject and their parents prior to the examination.
Method Of Obtaining Data: A pretested Questionnaire included questions regarding name, age, socioeconomic status, and three main questions regarding oral hygiene practices one regarding the tooth brushing frequency that was assessed by the following question: "How many times a day does your child brush his/her teeth?" with the answers of "twice or more/day," "once/day," "less than once/day," and "do not know." These answers were recorded as "twice or more/day; coded 1" and "less than twice/day (including 'do not know'); coded 2". Another question regarding the drinking sugar-sweetened beverages frequency was assessed by the following question: "How often does your child drink sugar-sweetened beverages?" with the answers of "several times/month or never; coded 1," "once/week; coded 2," "2- 3 times/week; coded 3," “4-6 times/week; coded 4," "once/day; coded 5" and "twice or more/day; coded 6." Third question was regarding "Snack-eating habits"that was assessed by the following question: "When does your child eat snacks?" with the answer of "does not eat snacks; coded 1," "eats snacks at a set time; coded 2" and "eats snacks freely whenever he/she wants; coded 3.'

Examination was carried out in a separate room in the school. The subjectswere made to sit comfortably on ordinary chair with back rest, with the examiner sitting in front of the chair. Type III examinations were followed using mouth mirror, probe and natural light The decayed filled (dft)index was selected for assessment of dental caries.

The statistical analysis was done using SPSS (Statistical Package for Social Sciences) Version 22.0 Statistical Analysis Software. Mediation analysis was done to find out the mediation effect of self control for that single question was asked to their parents that"How easily their childrens give up the habit which is not good for them from last one month. Other covariates like age, sex, socioeconomic status were regulated by Poisson regration analysis.

\section{Results}

The study participants comprised 450 primary schoolchildren (99.4\% response rate).

(Table I and Table ii) The overall caries prevalence in the study population was $51 \%$ with an overall mean dmft score of $2.08( \pm 2.97)$ of which decayed component comprised of 1.95 $( \pm 2.7)$, missing component $0.10( \pm 0.6)$ and filled component only $0.02( \pm 0.26)$. The mean dmft of males was $2.3( \pm 3.08)$ and of females was $1.90( \pm 2.90)$. 
(Table III) Documents the frequencies of oral health practices, Frequency of drinking sugar-sweetened beverages and Snack-eating habits with statistically significant differences by gender ,among the total population73 $.0 \%$ (328) girls and 66.0\%(297) boys brush their teeth Once a day,6.9(31) 7.3(32) Twice a day, 0.6(3) 0.7(3) More than twice day, 24.2(108) 17.5(78) Several times a week, 2.2(10) 0.7(3) DO not know respectively. (Table iv) The association between oral hygiene practices and caries occurrence was evident, those who cleaned their teeth at least once a day were less likely to have caries than those who cleaned their teeth rarely or never(OR=1.49,CI-1.17-1.89)

(Table $\mathrm{v}$ and vi) Logistic regression model was used to estimate 95\%confidence interval for examining the association between dental caries and sugar sweet beverages as well as Snack-eating habits and it was found that odds ratio of dental caries were greater among child's frequency intake of sugar sweet beverages $>3$ times/week and children's eating snacks freely whenever he/she wants as compared with the children with no SSB intake(OR=2.01,95\% CI=1.27,3.18) and does not eat snacks $(\mathrm{OR}=1.83,95 \% \mathrm{CI}=1.14,2.92)$

Table I

Distribution of variables regarding dental caries status and cumulative dmft

\begin{tabular}{|l|l|l|l|}
\hline VARIABLE & FREQUENCY $(\mathbf{n} \boldsymbol{=}=\mathbf{4 5 0})$ & PERCENT & MEAN? \pm ? SD \\
\hline dmft (cumulative): & 229 & 50.9 & $2.08 ? 2.97$ \\
\hline Decayed & 228 & 50.4 & $1.95 ? 2.77$ \\
\hline Missing & 21 & 4.1 & $0.10 ?: 0.61$ \\
\hline Filled & 5 & 1.0 & $0.02 ?: 0.264$ \\
\hline
\end{tabular}

Table ii

Variables regarding dental caries status $\mathrm{dmft}($ Gender-wise distribution):

\begin{tabular}{|l|l|l|l|}
\hline VARIABLE & FREQUENCY $(\mathbf{n} ?=$ ? 450) & PERCENT & MEAN? \pm ? SD \\
\hline male: & 142 & 39.2 & $2.3 \pm 3.08$ \\
\hline female: & 308 & 60.8 & 1.90122 .90 \\
\hline
\end{tabular}

Table iii Percentage Distribution of 6-7 year old school children according to various oral health practices

\begin{tabular}{|l|l|l|}
\hline Oral health practices(\%) & Gender \\
\hline Frequency of cleaning teeth & BOYS(\%) & GIRLS(\%) \\
\hline Once a day & $66.0(297)$ & $73.0(328)$ \\
\hline Twice a day & $6.9(31)$ & $7.3(32)$ \\
\hline More than twice day & $0.6(3)$ & $0.7(3)$ \\
\hline Several times a week & $24.2(108)$ & $17.5(78)$ \\
\hline DO not know & $2.2(10)$ & $0.7(3)$ \\
\hline
\end{tabular}

Table iv logistic regression analysis The Association Between Oral Hygiene Practices And Caries Occurrence

\begin{tabular}{|l|l|l|l|l|l|}
\hline $\begin{array}{l}\text { Independent } \\
\text { variable }\end{array}$ & B & S.E & P & Odds Ratio & C.I \\
\hline $\begin{array}{l}\text { Brushing } \\
\text { frequency }\end{array}$ & \multicolumn{5}{|l|}{} \\
\hline $\begin{array}{l}\text { Sometimes } \\
\text { or never }\end{array}$ & .231 & .106 & .004 & 1.43 & $1.13-1.81$ \\
\hline $\begin{array}{l}\text { More than } \\
\text { one a day }\end{array}$ & - & - & - & - & - \\
\hline
\end{tabular}

Table $\mathrm{v}$ association of sugar-sweetened beverages with dental caries

\begin{tabular}{|l|l|l|l|}
\hline Snack-eating habits & $\begin{array}{l}\text { total } \\
\mathrm{OR}=1.83,95 \% \mathrm{CI}=1.14,2.92\end{array}$ & $\begin{array}{l}\text { Dental } \\
\text { caries } \\
\text { experience } \\
\% \text { age }\end{array}$ & P value \\
\hline does not eat snacks & $5.5 \%(22.5)$ & $11 \%$ & \\
\hline eats snacks at a set time & $7.5 \%(33)$ & $22 \%$ & \multirow{2}{*}{0.04} \\
\cline { 1 - 1 } $\begin{array}{l}\text { eats snacks freely whenever } \\
\text { he/she wants }\end{array}$ & $87 \%(391)$ & $67 \%$ & \\
\hline
\end{tabular}

Table vi association of Snack-eating habits with dental caries

\begin{tabular}{|c|c|c|c|}
\hline $\begin{array}{l}\text { Frequency of drinking } \\
\text { sugar-sweetened } \\
\text { beverages }\end{array}$ & $\begin{array}{l}\text { total } \\
\mathrm{OR}=2.01,95 \% \\
\mathrm{CI}=1.27,3.18\end{array}$ & $\begin{array}{l}\text { Dental caries } \\
\text { experience \%age }\end{array}$ & $\mathrm{P}$ value \\
\hline $\begin{array}{l}\text { several times/month or } \\
\text { never }\end{array}$ & $2 \%(9)$ & 6.5 & \multirow{6}{*}{0.04} \\
\hline once/week & $0.5 \%(2)$ & 3.0 & \\
\hline 2- 3 times/week & $2.4 \%(10)$ & 5.1 & \\
\hline 4-6 times/week & $7.5 \%(33)$ & 22.0 & \\
\hline once/day & $0.6 \%(3)$ & 4.9 & \\
\hline twice or more/day & $87 \%(391)$ & 57.1 & \\
\hline
\end{tabular}

\section{Discussion:}

The present study demonstrated the associations between children's oral behaviours, and dental caries. It was found that sugar-sweetened beverages and Snack-eating habits, was significantly associated with high caries Similar findings were found in the study by Thornley et al. [2017] demonstrated that 8- to 11-year-old children attending schools with ban on sugary drinks, and providing free drinking water had significantly fewer caries. Another study conducted by Jones et al. [2010] also found that soft drinks, was significantly associated with high caries. This study makes the necessity to carry out more epidemiological surveys across the country territory and consequently to implement an ever-increasing number of prevention campaigns among the populations that may involve dental practitioners, paediatricians, teachers, parents, and children in order to reduce the incidence of the disease and to achieve what was asked by the World Health Organization (WHO) 
targets for 2010, which were to provide for a reduction of caries, with an average of caries-free participants equal to approximately $90 \%$ among preschool children. This study was limited because the sample was from a single region thus, the results cannot be generalized to the whole population.

\section{Conclusions:}

Consumption of sugar-sweetened beverages and Snackeating habits, was significantly associated with high caries among children. The Non-sugary snacks, meat snacks, and crispy packed snacks can lower the caries levels, while sugary beverages, sweetened milk, sweetened drinks, and soft drinks easy availability can increase caries levels. Having oral education integrated in the school curriculum can be a measure of significantly improving the oral behavior along with the better tooth brushing habits.By improving children's oral health behavior might decrease their dental caries by Strengthening their self control.

\section{References:}

1. N. B. Pitts, J. Boyles, Z. J. Nugent, N. )omas, and C. M. Pine,")edental caries experience of 11-year-old children in great britain. Surveys coordinated by the british association for the study of community dentistry in 2004/2005," Community Dental Health, vol. 23, no. 1, pp. 44-57, 2006.

2. G. Pizzo, M. R. Piscopo, D. Matranga, M. Luparello, I. Pizzo, and G. Giuliana, "Prevalence and sociobehavioral determinants of dental caries in Sicilian schoolchildren," Medical Science Monitor, vol. 16, no. 10, pp. PH83-PH89, 2010.

4. D. Duangthip, M. Jiang, C. H. Chu, and E. M. C. Lo, "Restorative approaches to treat dentin caries in preschool children: systematic review," European Journal of Paediatric Dentistry, vol. 17, no. 2, pp. 113-121, 2016.

5. P. A. Martins-J'unior, R. G. Vieira-Andrade, P. Corr^eaFaria, F. Oliveira-Ferreira, L. S. Marques, and M. L. Ramos-Jorge, "Impact of early childhood caries on the oral health-related quality of life of preschool children and their parents," Caries Research, vol. 47, no. 3, pp. 211-218, 2013.

6. L. Kragt, J. T. van der Tas, H. A. Moll et al., "Early caries predicts low oral health-related quality of life at a later age," Caries Research, vol. 50, no. 5, pp. 471-479, 2016.

7. J. T. van der Tas, L. Kragt, M. E. C. Elfrink et al., "Social inequalities and dental caries in six-year-old children from the Netherlands," Journal of Dentistry, vol. 62, pp. 18-24, 2017.

8. G. F. Ferrazzano, T. Cantile, L. Roberto et al., "Determination of the in vitro and in vivo antimicrobial activity on salivary Streptococci and Lactobacilli and chemical characterisation of the phenolic content of a Plantago lanceolata infusion," Biomedical Research International, vol. 2015, Article ID 286817, 8 pages, 2015 .

9. S. Tecco, A. Nota, S. Caruso et al., "Temporomandibular clinical exploration in Italian adolescents," Cranio, vol. 37, no. 2, pp. 77-84, 2019.

10. M. A. Peres, M. D. R. D. D. O. Latorre, A. Sheiham et al., "Social and biological early life influences on severity of dental caries in children aged 6 years," Community Dentistry and Oral Epidemiology, vol. 33, no. 1, pp. 53-63, 2005.

11. G. F. Ferrazzano, M. S. Scaravilli, and A. Ingenito, "Dental and periodontal health status in Campanian children and relation between caries experience and socio-economic behavioural factors," European Journal of Paediatric Dentistry, vol. 7, no. 4, pp. 174-178, 2006.

12. F. Schwendicke, C. E. D“orfer, P. Schlattmann, L. F. Page, W. M. )omson, and S. Paris, "Socioeconomic inequality and caries: a systematic review and metaanalysis," Journal of Dental Research, vol. 94, no. 1, pp. 10-18, 2015.

13. P. E. Petersen, "Sociobehavioural risk factors in dental cariesinternational perspectives," Community Dentistry and Oral Epidemiology, vol. 33, no. 4, pp. 274-279, 2005.

14. G. F. Ferrazzano, M. Coda, T. Cantile, G. Sangianantoni, and A. Ingenito, "SEM investigation on casein phosphopeptides capability in contrasting cola drinks enamel erosion: an in vitro preliminary study," European Journal of Paediatric Dentistry, vol. 12, no. 4, pp. 285-288, 2012.

15. S. Mummolo, E. Marchetti, M. R. Giuca et al., "In-office bacteria test for a microbial monitoring during the conventional and self-ligating orthodontic treatment," Head and Face Medicine, vol. 9, no. 1, p. 7, 2013.

16. N. Tinanoff, M. J. Kanellis, and C. M. Vargas, "Currentunderstanding of the epidemiology mechanisms, and prevention of dental caries in preschool children," Pediatric Dentistry, vol. 24, no. 6, pp. 543-551, 2002.

17. N. Tinanoff, "Dental caries risk assessment and prevention," Dental Clinics of North America, vol. 39, no. 39, pp. 709-719, 1995. 
18. T. A. Marshall, J. M. Eichenberger-Gilmore, B. A. Broffitt, J. J. Warren, and S. M. Levy, "Dental caries and childhood obesity: roles of diet and socioeconomic status," Community Dentistry and Oral Epidemiology, vol. 35, no. 6, pp. 449-458, 2007.

19. L. B. Christensen, S. Twetman, and A. Sundby, "Oral health in children and adolescents with different sociocultural and socio-economic backgrounds," Acta Odontologica Scandinavica, vol. 68, no. 1, pp. 34-42, 2010.

20. G. Carta, M. G. Cagetti, S. Sale et al., "Oral health inequalities in Italian schoolchildren-a cross-sectional evaluation," Community Dental Health, vol. 31, no. 2, pp. 123-128, 2014.

21. G. F. Ferrazzano, G. Sangianantoni, T. Cantile, and A. Ingenito, "Relationship between social and behavioural factors and caries experience in schoolchildren in Italy," Oral Health and Preventive Dentistry, vol. 14, no. 1, pp. 55-61, 2016.

22. A. M. Zicari, G. Marzo, A. Rugiano et al., "Habitual snoring and atopic state: correlations with respiratory function and teeth occlusion," BMC Pediatrics, vol. 12, p. 175, 2012.

23. T. Sarumathi, B. Saravanakumar, M. Datta, and T. Nagarathnam, "Awareness and knowledge of common oral diseases among primary care physicians," Journal of Clinical and Diagnostic Research, vol. 7, no. 4, pp. 768-771, 2013.

24. N. B. Pitts, D. J. Evans, and C. M. Pine, "British association for the study of community dentistry (BASCD) diagnostic criteria for caries prevalence surveys-1996/97," Community Dental Health, vol. 14, no. 1, pp. 6-9, 1997.

25. A. Noymer and R. Lee, "Immigrant health around the world:evidence from the world values survey," Journal of Immigrant and Minority Health, vol. 15, no. 3, pp. 614-623, 2013.

26. C. G. Victora, S. R. Huttly, F. C. Barros, C. Lombardi, and J. P. Vaughan, "Maternal education in relation to early and late child health outcomes: findings from a Brazilian cohort study," Social Science \& Medicine, vol. 34, no. 8, pp. 899-905,1992.

27. R. Perenboom, L. van Herten, H. Boshuizen, and G. van den Bos, "Life expectancy without chronic morbidity: trends in gender and socioeconomic disparities," Public Health Reports, vol. 120, no. 1, pp. 46-54, 2005.

28. E. Breeze, A. E. Fletcher, D. A. Leon, M. G. Marmot, R.

J. Clarke, and M. J. Shipley, "Do socioeconomic disadvantages persist into old age? Self-reported morbidity in a 29- year follow-up of the Whitehall study," American Journal of Public Health, vol. 91, no. 2, pp. 277-283, 2001.

29. J. P. Mackenbach, A. E. Kunst, A. E. Cavelaars, F. Groenhof, and J. J. Geurts, "Socioeconomic inequalities in morbidity and mortality in western Europe. )e EU working group on socioeconomic inequalities in health," ?e Lancet, vol. 349, no. 9066, pp. 1655-1659, 1997.

30. M. H. Hobdell, N. G. Myburgh, M. Kelman, and H. Hausen,"Setting global goals for oral health for the year 2010," International Dental Journal, vol. 50, no. 5, pp. 245-249, 2000.

31. B. K. Finch, "Socioeconomic gradients and low birthweight: empirical and policy considerations," Health Services Research, vol. 38, no. 6p2, pp. 1819-1842, 2003.

32. R. J. Hancox, B. J. Milne, D. R. Taylor et al., "Relationship between socioeconomic status and asthma: a longitudinal cohort study," ?orax, vol. 59, no. 5,pp. 376-380, 2004.

33. F. Sgolastra, F. Fidanza, D. Carosi, A. Petrucci, G. Cal’o, and R. Gatto, "An interdisciplinary approach to a survey on dental caries in a group of 3-year-olds in Ascoli Piceno (Italy)," European Journal of Paediatric Dentistry, vol. 11, no. 3, pp. 137-140, 2010 